\title{
Deteksi Molekuler Ekson 2 Gen Beta Globin pada Pasien Beta Talasemia Mayor di RSUD DR. Soeroto Ngawi menggunakan Metode Polymerase Chain Reaction- Single Strand Conformation Polimorfism
}

\section{Molecular Detection of Exon 2 of Beta Globin Gene from Thalassemia Beta Major Patients in RSUD DR. Soeroto Ngawi using Polymerase Chain Reaction-Single Strand Conformation Polimorfism Method}

\author{
Yahya Febrianto ${ }^{1, *}$, Ana Indrayati ${ }^{2,{ }^{*}}$, Elfahmi. ${ }^{3, *}$ \\ 1)2)Jurusan S2 Farmasi, Falkutas Farmasi, Universitas Setia Budi Surakarta-57127, Indonesia \\ *email: yahyafebri15@gmail.com \\ 3)Jurusan Farmasi, Falkutas Farmasi, Insitut Teknologi Bandung-40132, Indonesia
}

\begin{abstract}
ABSTRAK
Beta talasemia adalah kelainan darah herediter akibat kelainan genetik pada gen globin.Hal ini menyebabkan kerusakan pada sel darah merah sehingga harus dilakukan transfusi darah secara teratur.

Penelitian ini bertujuan mengetahui adanya mutasi pada ekson 2 gen beta globin dari pasien talasemia menggunakan metode PCR-SSCP.Sebanyak 5 sampel diisolasi DNA dan diamplifikasi dengan metode PCR.Selanjutnya hasil amplifikasi dikarakterisasi dengan metode elektroforesis. Region 2 gen beta globin merupakan hasil amplifikasi dari primer forward 4 dan primer reverse 5 dengan ukuran target $350 \mathrm{bp}$. Produk PCR dari setiap region kemudian dianalisis lebih lanjut dengan metode SSCP. Hasil analisis menunjukkan terdapat indikasi mutasi pada sampel 1,2,3,6 dan tidak terdapat mutasi pada sampel 5

Berdasarkan hasil penelitian yang dilakukan dapat ditarik kesimpulan bahwa metode PCR-SSCP dapat mengetahui jenis dan letak mutasi pada ekson 2 gen $\beta$ globin dari pasien $\beta$ talassemia.
\end{abstract}

Kata kunci : talasemia, beta talasemia, pcr, sscp

\section{ABSTRACT}

Beta thalassemia is a hereditary blood disorder that caused by genetic disorder of globin gene.The condition leads to red blood cell damage so regular blood transfusion is needed.

This study was aimed to determine the presence of mutations in exon 2 gene beta from beta globin thalassemia patients using PCR-SSCP method. The DNA was isolated from 5 samples and amplified using PCR. The amplified product was characterizaed using electrophoresis. Region 2 of beta globin was product of primer forward 4 and primer reverse 5 with $350 \mathrm{bp}$ of target size. The PCR products of each region then futher analyzed using SSCP method. There was indication of mutation in 1,2,3,and 6 samples whereas no mutation in sample 5.

Based on the results of research can be concluded that PCR-SSCP method can be used to determine the type and location of mutations in exon 2 genes $\beta$ globin from $\beta$ thalassemia.

Keywords: thalassemia, beta thalassemia, pcr, sscp 


\section{PENDAHULUAN}

Talasemia merupakan kelainan genetik yang disebabkan adanya mutasi gen penyandi rantai globin, yaitu gen HBA yang menyandi a globin atau gen HBB yang menyandi $\beta$ globin (Galanello, 2010). Talasemia disebabkan oleh penurunan kecepatan sintesis atau kemampuan produksi satu atau lebih rantai globin $\alpha$ dan $\beta$. Hal ini terjadi karena delesi total atau parsial, substitusi, atau insersi nukleotida gen globin. Beta talassemia adalah kelainan darah herediter yang ditandai dengan berkurangnya kadar haemoglobin akibat sintesis rantai globin yang tidak seimbang. Kondisi tersebut menyebabkan anemia dan harus di lakukan penanganan melalui transfusi darah secara teratur agar keadaan kembali normal. Penderita thalassemia yang melakukan transfusi darah secara rutin dapat meningkatkan zat besi dalam tubuh (Weatherall,1997).

Salah satu cara yang sering digunakan untuk mengetahui pembawa sifat $\beta$ talassemia adalah dengan analisis hematologi. Pembawa sifat $\beta$ talassemia dapat dilihat dengan gejala mikrositik dan penurunan jumlah $\mathrm{Hb}$ pada eritrosit (Cao \& Galanello, 2010). Selain itu digunakan metode PCRSSCP sebagai metode untuk mendeteksi mutasi pada pasien $\beta$ talasemia mayor. Metode ini telah dikembangkan untuk mendeteksi adanya mutasi pada pembawa sifat thalasemia (Priyambodo, 2014; Onggo, 2014).

Individu yang terdiagnosa $\beta$ talassemia mayor di RSUD Dr. Soeroto Kabupaten Ngawi dideteksi melalui pemeriksaan $\mathrm{Hb}$ elektroforesis.
Pemeriksaan berbasis molekuler untuk mengetahui jenis dan letak mutasi belum pernah dilakukan. Penelitian ini melakukan deteksi molekuler dengan metode PCR-SSCP untuk mengetahui mutasi pada ekson 2 gen BETA globin di RSUD Dr. Soeroto Kabupaten Ngawi. Berdasarkan penelitian Priyambodo, 2014, dilaporkan bahwa analisis PCR-SSCP terhadap individu $\beta$ talassemia dapat dilakukan untuk mengetahui mutasi pada gen $\beta$ globin (Priyambodo, 2014).

\section{METODE PENELITIAN}

Alat dan Bahan

1. Alat

Alat yang digunakan dalam penelitian ini meliputi alat-alat gelas berupa gelas beker, gelas ukur, Erlenmeyer, pipet tetes, corong, pengaduk, pipet ukur beserta pipet pump berfungsi untuk preparasi larutan baik bahan, sampel dan reagen; microcentrifuge tube (mictotube) 1,5 mL dan 0,2 $\mathrm{mL}$ sebagai tempat penyimpanan sampel ; mikropipet untuk mengambil sampel dan bahan dalam skala mikroliter; neraca analitik untuk menimbang bahan, Erlenmeyer untuk tempat pencampuran bahan, vorteks untuk homogenasi larutan, sentrifuge untuk memisahkan komponen larutan berdasar berat jenis, incubator sebagai tempat inkubasi, microwave untuk pembuatan gel agarose, lemari pendingin sebagai tempat penyimpanan bahan, rangkaian alat elektroforator horizontal untuk memisahkan komponen atau molekul berdasarkan perbedaan tingkat migrasinya dalam sebuah medan listrik, UV transiluminator untuk visualisasi pita DNA, thermocycler untuk amplifikasi 
DNA, fluorometer untuk mengukur konsentrasi sampel, program Chromas Lite 2.1 untuk membaca DNA hasil sekuensing, software MEGA 6.0 untuk alignment dan analisis sekuen DNA, dan kamera digital untuk dokumentasi selama penelitian.

2. Bahan

Bahan yang digunakan adalah 5 sampel darah pasien thalasemia yang rutin melakukan tranfusi di RSUD Dr. Soeroto Kabupaten Ngawi, disimpan dalam tube $B D$ vacutainer EDTA dan satu sampel normal atau control negative digunakan sebagai pembanding dalam penelitian ini. Akuades steril, Geneaid Genomic DNA Mini Kit (Blood/Cultured Cell), PCR master mix KAPA 2G fast ready mix, primer forward dan reverse spesifik untuk pada gen beta globin, DNA loading dye, Geneaid100bp plus DNA ladder, fluoroceft, gel agarosa, ethanol absolut 96\%, buffer Tris Borat EDTA (TBE), loading buffer (campuran bromo phenol blue, formamide, EDTA, gliserol), gel poliakrilamid (acrylamide:bis-acrylamide 29:1). ethidium bromide dan pipet tip.

Jalannya Penelitian

1. Pengambilan Sampel

Sampel darah diperoleh dari pasien beta thalasemia mayor yang rutin melakukan transfusi di RSUD Dr. Soeroto kabupaten Ngawi. Sampel darah disimpan dalam tabung vacutaine EDTA $3 \mathrm{ml}$ dan dimasukan dalam freezer- $20^{\circ} \mathrm{C}$.

2. Isolasi DNA

Isolasi DNA sampel dilakukan dengan GSYNC $^{\text {TM }}$ DNA Ekstraction kit sesuai dengan protocol kit. Langkah-langkah isolasi DNA.
Alur Penelitian

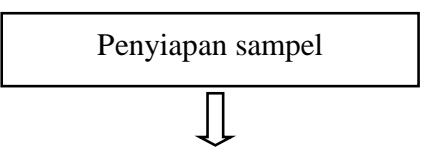

Isolasi DNA

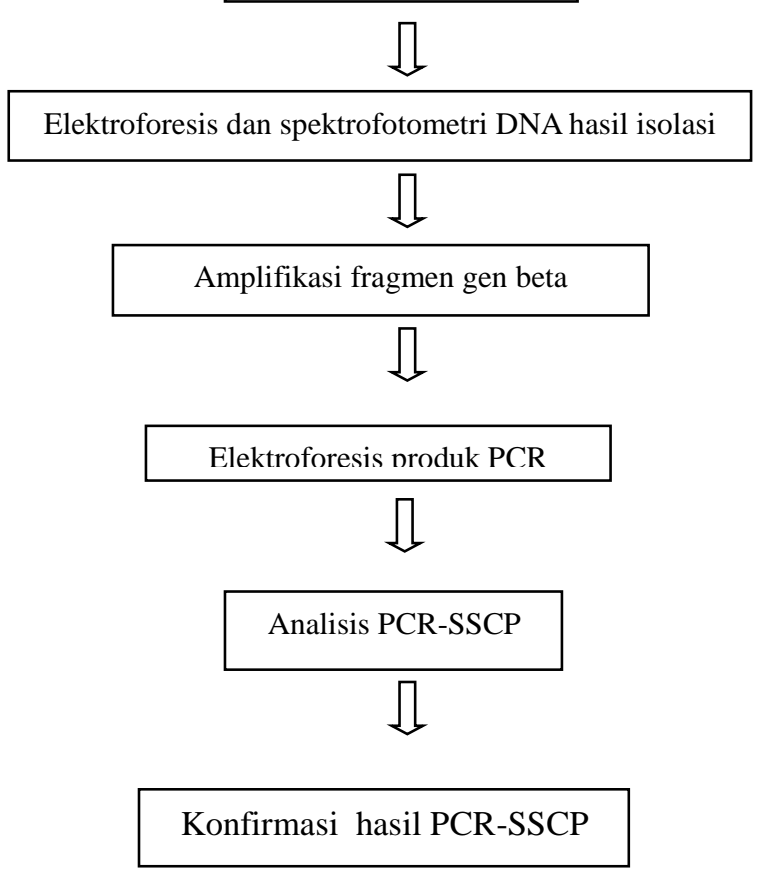

a. Lisis Sel

Sebanyak $200 \mu$ sampel darah diambil dan dimasukkan dalam tabung microtube $1,5 \mathrm{ml}$ dan menambahkan 20 $\mu$ Proteinase- $\mathrm{K}$ dan di inkubasi pada suhu $60^{\circ} \mathrm{C}$ selama 5 menit, kemudian ditambahkan GB buffer sebanyak 200 $\mu \mathrm{l}$ dan dihomogenkan dengan vortex. Selanjutnya sampel diinkubasi pada suhu $60^{\circ} \mathrm{C}$ selama 5 menit, selama inkubasi microtube dibolak-balik selama 2 menit.

b. Pengikatan DNA

Setelah inkubasi selesai, sebanyak 200 $\mu \mathrm{l}$ etanol absolut ditambahkan dalam sampel lalu divorteks kemudian dipindahkan dalam purification columm (kolom GD ) yang diletakakan dalam 
tabung pengumpul berukuran $2 \mathrm{ml}$. Sampel kemudian dipindahkan dalam kolom GD. Sampel selanjutnya di sentrifugasi pada 12.000 rcf selama 5 menit kemudian larutanan hasil sentrifugasi dibuang dan kolom $G D$ ditempatkan pada tabung pengumpulyang baru.

c. Pencucian

Sebanyak $400 \mu \mathrm{l}$ wash buffer 1ditambahkanke dalam kolom GD dan disentrifugasi pada 12.000 rcf selama 2 menit. Larutan sisa pencucian pada tabung pengumpul dibuang. Kolom GD dimasukan ke dalam tabung pengumpul yang baru dan ditambahkan $600 \mu \mathrm{l}$ wash buffer II dan selanjutnya disentrifugasi pada $12.000 \mathrm{rpm}$ selama 2 menit. Larutan sisa pencucian dalam tabung pengumpul dibuang, kemudian kolom GD disentrifugasi lagi dengan kecepatas 12.000 rpm selama 4 menit.

d. Pengelusian

Setelah selesai, kolom GD ditempatkan dalam tabung microtube $1,5 \mathrm{ml}$, kemudian ditambahkan $75 \mu$ l buffer elusi yang diinkubasi pada suhu $60{ }^{\circ} \mathrm{C}$. Selanjutnya larutan diinkubasi pada suhu kamar selama 5 menit dan disentrifugasi pada 12.000 rcf selama 2 menit. Proses elusi diulangi 2 kali untuk memaksimalkan pelepasan DNA dari silica gel pada kolom GD. Selanjutnya, kolom $G D$ dikeluarkan dari microtube $1,5 \mathrm{~mL}$ dan disimpan di dalam lemari pendingin.

3. Fluorometer dan Elektroforesis DNA

Pada penelitian ini digunakan uji kuantitatif dengan metode fluorometri, Qubit fluorometer adalah perangkat kuantifikasi DNA yang didasarkan pada intensitas fluoresensi dari label fluorosen yang mengikat DNA beruntai ganda (sdDNA) (Nakayama et al. 2016), selanjutanya skema fluoromrter disiapkan microtube berisi sampel dan 2 microtube tambahan untuk standard atas dan bawah (nol). Selanjutnya dilakukan pembuatan larutan uji (Working Solution) dengan cara : Larutan dihomogenasikan dengan vortex selama 2-3 detik, dipastikan tidak ada gelembung terbentuk. Larutan standard dibuat dengan cara Sebanyak 1-20 $\mu \mathrm{L}$ sampel dicampurkan dengan 199-180 $\mu \mathrm{L}$ larutan uji untuk mendapatkan larutan dengan volume akhir $200 \mu \mathrm{L}$. Microtube berisi sampel divorteks selama 2-3 detik tanpa terbentuk gelembung kemudian diinkubasi pada suhur uang selama 2 menit. Setelah itu, dilakukan pembacaan dengan mesin Qubit yang telah dinyalakan. Larutan uji dibaca terlebih dahulu selanjutnya sampel. Microtube dimasukkan pada Qubit fluorometer kemudian ditekan "Read" dan ditekan "Save" untuk menyimpan data.

Uji kualitatif dengan elektroforesis pada gel agarosa $0,8 \%$. Mula-mula sebanyak 0,32 gram agarosa ditimbang kemudian ditambahkan $40 \mathrm{~mL}$ Tris Borate-EDTA (TBE) 1X dan dilarutkan sampai homogen. Larutan tersebut dipanaskan dalam microwave selama 30 detik. Setelah sedikit dingin ditambahkan fluoroceft sebanyak $2 \mu \mathrm{L}$ dan dilarutkan hingga homogen. Gel dituang pada cetakan yang telah diberi sisir untuk sumuran. Gel didiamkan hingga mengembang lalu sisir dilepas dan gel dipindahkan ke dalam alat 
elektroforesis dan ditambahkan dengan TBE $1 \mathrm{x}$ hingga gel terendam.

Sumuran pertama diisi sebanyak $3,5 \mu \mathrm{L}$ marker DNA berupa 100 pb. Hasil isolasi DNA diambil sebanyak $5 \mu \mathrm{L}$ dan dicampur dengan $1 \mu \mathrm{L}(6 \mathrm{x})$ loading dye. Campuran DNA dan loading dye dimasukkan dalam sumuran gel agarosa. Elektroforesis DNA dilakukan dengan menghubungkan katoda dan anoda pada sumber tegangan 100 volt selama 15 menit. Pengamatan pita DNA dilakukan dengan menggunakan UV transiluminator.

4. Amplifikasi Region 2 Gen $\beta$-globin Hasil isolasi DNA akan digunakan sebagai cetakan pada proses amplifikasi dengan metode polymerase chain reaction (PCR). PCR dilakukan berdasarkan prosedur KAPA Biosystem (2013). PCR mix dibuat dengan menggunakan PCR Master mix KAPA2G fast ready mix,

Setelah semua komponen dimasukan ke dalam tabung PCR, selanjutnya dimasukan ke dalam mesin thermal cycler. Kondisi siklus PCR yang digunakan untuk amplifikasi gen $\beta$ globin adalah sebagai berikut: (Pryambodo, 2014)

5. Elektroforesis Hasil Amplifikasi PCR

Hasil PCR dielektroforesis pada gel agarosa dengan konsentrasi $2 \%$. Sebanyak 0,8 gram agarosa ditimbang kemudian ditambahkan $100 \mathrm{~mL}$ Tris Borate-EDTA (TBE) 1X dan dilarutkan sampai homogen. Larutan tersebut dipanaskan dalam microwave selama 50 detik. Setelah sedikit dingin ditambahkan fluoroceft sebanyak 3,5 $\mu \mathrm{L}$ dan dilarutkan hingga homogen. Gel dituang pada cetakan yang telah diberi sisir untuk sumuran. Gel didiamkan hingga mengembanglalu sisir dilepas dan gel dipindahkan ke dalam alat elektroforesis dan ditambahkan dengan TBE 1x hingga gel terendam. Sumuran pertama diisi dengan sebanyak $3 \mu \mathrm{L}$ marker DNA berupa 100 pb. Sampel diambil sebanyak $4 \mu \mathrm{L}$ dan dimasukkan dalam sumuran gel agarosa. ElektroforesisDNA dilakukan dengan menghubungkan katoda dan anoda pada sumber tegangan 50 volt. Elektroforesis dihentikan setelah migrasi DNA mencapai 2/3 panjang gel yang ditunjukkan dengan warna biru pada gel agarosa. Pengamatan pita DNA dilakukan dengan menggunakan UV Transiluminator.

6. Analisis PCR-SSCP

Analisis polymerase chain reactionsingle strand conformation polymorphism (PCR-SSCP) dilakukan berdasarkan metode Fitriani (2009) dengan modifikasi sebagai berikut :

a. Pembuatan gel

Larutan gel disiapkan dengan Erlenmeyer $125 \mathrm{ml}$ yang terdiri atas 5,6 $\mathrm{ml}$ aquabides 2,6 ml, poliakrilamid 30\% (akrilamid : bisaakrilamid 29:1), $1 \mathrm{ml}$ TBE 10x, 0,68 ml gliserol 87\%, $45 \mu \mathrm{l}$ ammonium persulfat $10 \%$, dan $10 \mu \mathrm{l}$ tetramethyl ethylene diamine (TEMED).Setelah TEMED ditambahkan, larutan gel dihomogenkan, selanjutnya segera dituangkan dengan menggunakan mikropipet ke dalam cetakan. Sisir dipasang pada cetakan dan gel dibiarkan selama 60 menit.

Setelah 60 menit, gel dipasang pada tangki elektroforator vertikal dan ditambahkan TBE 1,5x hingga mencapai batas kolom. Sisir diangkat 
dengan hati-hati dan dilakukan prerunning selama 20 menit.

b. Penyiapan sampel

Sebanyak $10 \mu \mathrm{l}$ produk PCR ditambahkan $15 \mu \mathrm{l}$ loading buffer dihomogenasi dengan vortex.

Campuran sampel dan loading buffer dipanaskan dalam waterbath pada suhu $95^{\circ} \mathrm{C}$ selama 10 menit untuk denaturasi. Setelah proses denaturasi, sampel segera dimasukkan freezer suhu $-20^{\circ} \mathrm{C}$ selama 10 menit. Setelah proses thawing, sebanyak $25 \mu \mathrm{l}$ campuran tersebut dimasukkan kedalam masing-masing sumuran gel. Elektroforesis dilakukan dengan TBE $0,5 \mathrm{x}$ pada $100 \mathrm{~V} 50 \mathrm{~mA}$ selama 100 menit.

c. Pewarnaan

Gel dilepas dari gelas, lalu diencerkan dalam larutan etidium bromida selama 45 menit dan diamati dengan UV transilluminator. Hasil didokumentasikan dengan kamera digital.

d. Interpretasi hasil

Interpretasi data dilakukan dengan mendeskripsikan pita hasil SSCP dengan membandingkan perbedaan jarak migrasi pita (Single strand DNA) subyek yang diteliti dengan individu normal. Individu yang memiliki genotip homozigot, baik homozigot dominan maupun resesif menunjukkan dua pita DNA pada gel, sedangkan individu heterozigot menunjukan tiga atau empat pita DNA.

\section{HASIL DAN PEMBAHASAN}

a. Identifikasi Sampel

Penelitian ini menggunakan sampel darah pasien Beta Thalasemia RSUD Dr.Soeroto Ngawi Jawa Timur, dengan prosedur pengambilan sampel memenuhi kelayakan etik atau Ethical Clearance.

Identifikasi Ethical Clearance digunakan untuk memenuhi kelayakan etik dalam penggunaan sampel melibatkan makluk hidup yang menyatakan bahwa suatu penelitian layak untuk dilakukan.

b. Pengambilan Sampel

Sampel darah diperoleh dari 5 (Sembilan) pasien beta thalasemia mayor yang rutin melakukan transfusi di RSUD Dr. Soeroto kabupaten Ngawi. Sampel darah disimpan dalam tabung vacutaine EDTA $3 \mathrm{ml}$ dan dimasukan dalam freezer-200C.

c. Hasil Isolasi DNA

Hasil Isolasi DNA dilakukan menggunakan kit isolasi yang dapat mengekstraksi DNA dari darah beku dan telah ditambahkan zat antikoagulan (EDTA). DNA hasil isolasi selanjutnya dilakukan uji baik secara kualitatif maupun kuantitatif, uji kualitatif DNA dilakukan dengan elektroforesis pada gel agarosa dengan konsentrasi 0,8\%. Hasil elektroforesis DNA seluruh sampel disajikan pada Gambar 1. Selanjutnya dilakukan Uji kuantitatif DNA dapat dilakukan dengan metode fluorometri untuk mngetahui konsentrasi DNA hasil isolasi. Hasil spektrofotometri sampel disajikan pada Gambar 1.

Pada elektroforesis DNA seluruh sampel menghasilkan pita DNA yang terlihat jelas. Selain 5 sampel tersebut isolasi dan elektroforesis juga dilakukan pada satu sampel normal $(\mathrm{N})$ dan satu sampel control positif $(\mathrm{K}+)$ (gambar tidak ditampilkan). Sampel normal digunakan sebagai kontrol negatif 
mutasi. Sedangkan sampel $\mathrm{K}+$ yang digunakan merupakan sampel darah dari penyandang thalassemia yang telah diketahui mutasinya melalui sekuensing DNA. Kedua kontrol ini digunakan untuk mengevaluasi setiap tahapan metode dari uji molekuler yang dilakukan.

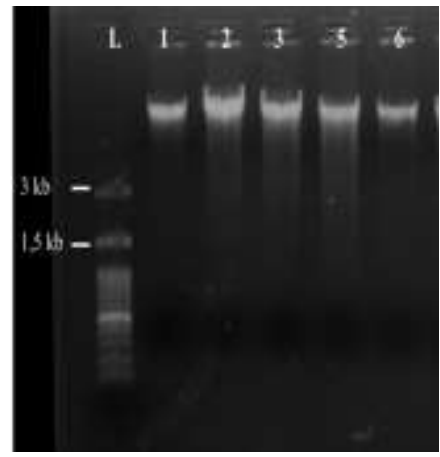

Gambar 1. Elektroforesis DNA seluruh sampel

Ukuran genom manusia berdasarkan International Human Genome Sequencing Consortium secara keseluruhan diestimasikan $2.916 \mathrm{gb}$, dengan ukuran molekul DNA pada 23 kromsosomnya berkisar dari 21,8 mg (kromosom $Y$ ) hingga 2692,9 mg (kromosom 1) dan molekul DNA pada mitokondria yang berukuran $16.569 \mathrm{bp}$ (Lander et al.,2001). Dikarenakan ukuran DNA nya yang besar sehingga pada hasil elektroforesis pita DNA genom sampel terlihat jauh diatas marker. Setiap sampel menampilkan pita dengan ketebalan yang beragam berdasarkan konsentrasi DNA yang diperoleh dari isolasi yang dilakukan.

Konsentrasi DNA sampel

Nilai konsentrasi DNA hasil isolasi sampel dengan metode fluorometri menggunakan Qubit Fluorometer ditampilkan pada Tabel 1. Pada sampel, konsentrasi DNA berkisar 55,2$82 \mathrm{ng} / \mu \mathrm{L}$. Qubit Fluorometer adalah perangkat kuantifikasi DNA yang didasarkan pada intensitas fluoresensi dari label fluorosen yang mengikat DNA beruntai ganda (sdDNA) (Nakayama et al. 2016). DNA pada sampel menunjukkan, konsentrasi yang bervariasi dengan sesuai dengan kenampakan tebal tipis pita pada elektroforesis. Setiap sel diploid manusia mengandung sekitar 6 pg DNA. Untuk isolasi DNA dari darah tepi umumnya diperoleh $30 \mathrm{ng} / \mu \mathrm{L}$ hingga 60 $\mathrm{ng} / \mu \mathrm{L}$ dari $1 \mathrm{ml}$ darah yang berasal dari 5-10 juta leukosit (Baechtel, 1989).

\begin{tabular}{lll}
\hline No & $\begin{array}{l}\text { Nama } \\
\text { Sampel }\end{array}$ & $\begin{array}{l}\text { Konsentrasi } \\
(\mathbf{n g} / \boldsymbol{\mu l})\end{array}$ \\
\hline 1 & Sampel 1 & 63,6 \\
2 & Sampel 2 & 68 \\
3 & Sampel 3 & 82 \\
4 & Sampel 5 & 70,8 \\
5 & Sampel 6 & 62 \\
\hline
\end{tabular}

Secara umum konsentrasi DNA sampel pada penelitian ini sesuai referensi. Adanya variasi pada konsentrasi DNA dapat disebabkan karena perbedaan kualitas darah yang dipengaruhi lamanya waktu penyimpanan darah.

Hasil amplifikasi region gen beta globin DNA sampel diamplifikasi sesuai dengan region target. Penelitian ini mengacu pada pembagian region berdasarkan Gupta and Argawal (2003) dengan hanya 3 region saja yang digunakan yaitu region I, II dan IV. Pemilihan 3 region ini didasarkan atas keberadaan daerah ekson pada ketiga region tersebut. Mutasi yang terjadi pada ekson dapat menyebabkan 
kesalahan translasi pada sintesis asam amino sehingga dapat memberikan efek secara langsung pada rantai beta globin yang disintesis, pada penelitian ini difokuskan pada region II yang didalamnya terdapat ekson 2. Proses amplifikasi atau perbanyakan DNA dilakukan dengan metode PCR.

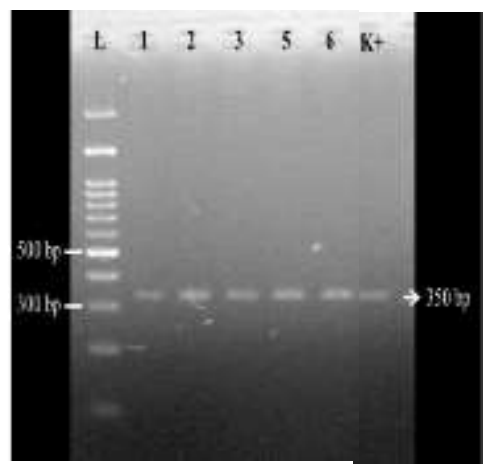

Gambar 2. Hasil elektroforesis region II gen beta globin pada sampel

Pada gambar diatas menunjukkan hasil amplifikasi dari region II gen beta globin. Region II merupakan hasil amplifikasi dari primer forward 4 dan primer reverse 5 dengan target yaitu 350 bp. Region ini mencakup sebagian daerah intron 1, seluruh daerah ekson II dan sebagian daerah intron 2 gen beta globin.

Pada PCR terjadi amplifikasi atau penggandaan sekuen DNA yang diinginkan berdasarkan pemilihan primer untuk reaksi. Penggandaan DNA secara alami terjadi pada organisme melalui proses replikasi DNA dengan DNA helikase berperan dalam membuka pita ganda DNA sehingga DNA polimerase dapat memulai penggandaan. Pada PCR peran DNA helikase digantikan dengan menaikkan suhu ketika reaksi sehingga DNA terdenaturasi dan terbentuk untai tunggal DNA, kemudian titik untuk memulai polimerasi ditentukan oleh primer yang spesifik yang melekat pada untai tunggal dan kemudian oleh DNA polimerase penggandaan sekuen DNA target terjadi. PCR memerlukan enzim polimerasi DNA yang tahan terhadap panas (thermostable) contohnya Taq Polymerase (Bustin, 2010). Produk PCR dari tiap region inilah yang selanjutnya dilakukan SSCP. Visualisasi produk PCR pada tiap region dapat ditampilkan pada Gambar 2.

Hasil SSCP region gen beta globin Single Strand Conformation Polymorphism atau yang dikenal sebagai SSCP merupakan salah satu teknik untuk mendetesi mutasi. Prinsip dari SSCP adalah fakta bahwa single strand DNA (ssDNA) memiliki konformasi tertentu. Perubahan konformasi karena adanya perubahan basa pada sekuen DNA dapat menyebabkan perbedaan migrasi ssDNA pada elektroforesis sehingga DNA wild-type atau normal dan DNA yang mengalami mutasi akan menunjukkan pola pita yang berbeda. Analisis SSCP sendiri terdiri dari 4 tahapan yaitu 1) amplifikasi target DNA dalam hal ini yaitu region II gen beta globin, 2)denaturasi dsDNA dari produk PCR menjadi ssDNA dengan penambahan agen denaturasi (formamida) dan pemanasan, 3)pendinginan hasil denaturasi DNA yaitu ssDNA untuk memaksimalkan self-annealing sehingga membentuk konformasi tertentu, dan 4). Deteksi perbedaan migrasi konformasi ssDNA pada elektroforesis kondisi non denaturasi (Dong dan Zhu, 2005). 
Elektroforesis yang dilakukan adalah PAGE atau Polyacrilamide Gel Electroforesis konsentrasi 39,7\% dengan elektroforator vertical. Hasil dari analisis SSCP pada region II yang didalamnya juga termasuk bagian ekson 2 yang dilakukan ditampilkan pada Gambar 3

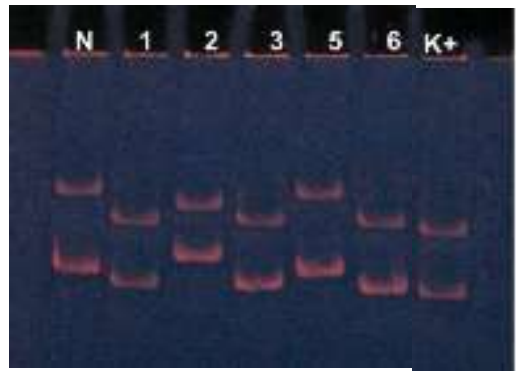

Gambar 3.Hasil SSCP pada region II. Pola pita pada gel poliakrilamid.

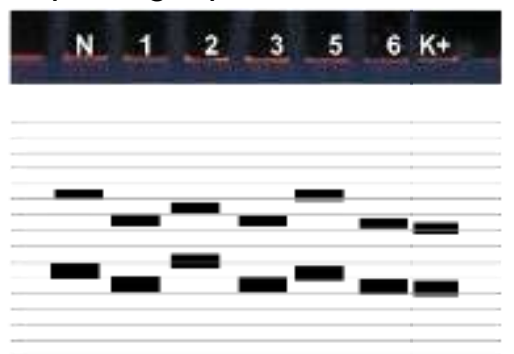

Gambar 4. Hasil SSCP region II gen beta globin pada sampel. Skema pola pita gel poliakrilamid.

Pada region II gen beta globin yang telah dilakukan analisis SSCP, lima sampel manunjukkan dua pita. Terdapat sau sampel yang menunjukkan pola pita yang sama dengan sampel $\mathrm{N}$ yaitu sampel 5 . Hal ini menunjukkan pada 4 sampel) ada indikasi mutasi atau perbedaan sekuen pada region ini karena terbentuk konformasi yang berbeda sehingga terjadi perbedaan migrasi dan menampilkan pola pita yang berbeda- beda. Indikasi adanya mutasi pada sekuen region II gen beta globin diketahui dengan melihat adanya pola pita yang berbeda dengan kontrol negative (sampel $\mathrm{N}$ ). Berdasarkan pada region II, terdapat 4 sampel yang berdasarkan analisis SSCP ada indikasi mutasi sedangkan 1 sampel sisanya tidak ada indikasi.

\section{KESIMPULAN}

Berdasarkan hasil penelitian yang dilakukan dapat ditarik kesimpulan bahwa metode PCR-SSCP dapat mengetahui jenis dan letak mutasi pada ekson 2 gen $\beta$ globin dari pasien $\beta$ talassemia. Hasil analisis sampel pasien RSUD Dr. Soeroto Kabupaten Ngawi menunjukkan indikasi mutasi pada sampel 1,2,3,6 dan tidak terdapat mutasi pada sampel 5 .

\section{DAFTAR PUSTAKA}

Bustin, S. A., 2010. The PCR Revolution: Basic Technologies and Applications. Cambridge University Press. New York. hal 17.

Calzolari, Roberta, McMorrow Calzolari, R., McMorrow, T., Yannoutsos, N., Langeveld, A., \& Grosveld, F. 1999. Deletion of a Region that is a Candidate for the Difference between the Deletion Forms of Hereditary Persistence of Fetal Hemoglobin and $\beta$-thalassemia Affets beta-Globin Gene but not $\hat{y}$-Globin Gene Expression. European Molecular Biology Organization 18(4): 949 - 958.

Danckwardt, S., Neu-yilik, G., Thermann, R., Frede, U., Hentze, 
M.W., nd aKulozik, A.E. 2012. Abnormally spliced $\beta$-globin mRNAs: a single point mutation generates transcripts sensitive and insensitive to nonsensemediated mRNA decay. Blood 99(5): 1811-7.

Dong Y. Zhu H. 2005. Single-strand conformational polymorphism analysis: basic, principle and routine practice. Methods $\mathrm{Mol}$ Med; 108:149-157.

F. S. Baechtel, 1989. The extraction, purification and quantification of DNA. in Proceedings of the International Symposium on theForensic Aspects of

Galanello, R., and Origa, R., 2010, Beta Thalasemia, Orphanet Journal of Rare Disease, 5:11.

Galanello, R., Cao, A. 2011. Alphathalassemia. Genetics in Medicine, 13(2): 83-88

Gruszczynska J, Brokowska K, Charon KM, \& Swiderek WP. 2005. Restriction Fragment Length Polymorphism of Exon 2 OvarDRB1 Gene in Polish Heath Sheep and Polish Lowland Sheep. J Appl Genet 46:311314.

Guo, CY., Xu, XF., Wu, JY., \& Liu, SF. 2008. PCR-SSCP-DNA Sequencing Method in Detecting PTEN Gene Mutation and its Significance in Human Gastric Cancer. World Journal of Gastroenterology, 14(24): 3804 3811.
Gupta, A. 2003. Efficiency and cost effectiveness:

PAGE-SSCP versus MDE and Phast gels for the identification of unknown thalassaemia mutations. Molecular Pathology 56(4): 237239.

Gupta, A. and Agrawal, S., 2003, Efficiency and Cost Effectivennes : Page-SSCP versus MDE and Phast Gels for the Indentification of Unknown $\beta$ Thalasemia Mutation, Jurnal Molecular Pathology, 56, 237239.

Handayani, N.S.N., and Purwanto, R. 2015. Cd35 (Del C) Frameshift Mutation in Exon 2 of $\beta$-Globin Gene on $\beta$-Thalassemia Carriers. Biomedical Engineering 1(1):1923.

Handayani,N.S.N. dan Onggo, A.T., 2014, Identifiasi Mutasi Gen $\beta$ Globin Ekson 1 pada Pembawa Thalasemia, Jurnal Biogenesis, Vol. 2,I, hal. 63-69.

Handayani,N.S.N. dan Purwanto, R., 2015, $C_{35}$ (del C) Frameshit Mutation in Exon 2 of $\beta$ Globin Gene on $\beta$ Thalasemia Carriers, Biomedical Engineering, vol 1(1), 19-23.

Harteved, C.,L., and Higgs, D.,R.,2010, Alpha Thalasemia, Orphanet Journal of Rare Disease, 5:13.

Hoffbrand, A.V., Pettit, J.E., Moss, P.A.H. 2006. Essential Haematology Fifth Edition. Massachusetts: Blackwell Science, Inc. 
Kakavas, V, Konstantinos,.., Plageras, P., Vlachos, Antonios, Papaioannou, A. 2008. PCRSSCP: A Method for the Molecular Analysis of Genetics Disease. Mol Biotechnol (2008) 38:155-163

Kanavakis E, Traeger-Synodinos J, Vrettou C, Maragoudaki E,Tzetis M, Kattamis C. Prenatal diagnosis of the thalassemia syndromes by rapid DNA analytical methods. Mol Hum Reprod 1997;3:523-8.

Lander, E. S., Linton, L. M., Birren, B., et al. 2001. Initial sequencing and analysis of human genome. Nature, 409: 860-920.

Lanni F, Gani RA, Widuri, Rochdiyat W, Verawaty B, Sukmawati, dkk. Bthalassemia and hemoglobin traits in Yogyakarta population. Dipresentasikan pada 11th International Conference on Thalassaemia and Haemoglobinophaties \& 13rd International TIF Conference for Thalassaemia patients and parents. Singapore; 811 Oktober 2008.

Lanni, F. 2002. Heterogenitas Molekular Gena Globin-â di Indonesia: Kaitannya dengan Pola Penyebaran Thalassemia-â serta Afinitas Genetik antar Populasi di Indonesia. Disertasi, tidak diterbitkan. UGM. Yogyakarta.

Nakayama Y. Yamaguchi H. Einaga N. and Esumi M. 2016. Pitfalls of DNA Quantification Using DNA-
Binding Fluorescent Dyes and Suggested Solutions. Plos One;11(3): e0150528. doi: $10.1371 /$ journal.pone.015052 $\underline{8}$

Peixeiro, I., Silva, A., and Romao, L. 2011. Control of human -globin mRNA stability and its impact on beta-thalassemia phenotype. Haematologica 96(6): 905-913.

Priyambodo dan Handayani, N.S.N., 2014, Deteksi mutasi Ekson 2 Gen $\beta$-Globin dan Daerah Pengapitnya Pada Pembawa Sifat $\beta$-Thalasemia dengan Metode Polymerase Chain Reaction-Singgle Strand Conformation Polymorphism (PCR-SSCP), Prosiding Seminar Nasional dan Rapat Tahunan Bidang MIPA, Fakultas MIPA Institut Pertanian Bogor.

Raut, AA., Kumar, A., Kala, SN., Chhokar, V., Rana, N., Beniwal, V., Jaglan, S., Samuchiwal, S.K., Singh, J.K., \& Mishra, A.. 2012. Identification of Novel Single Nucleotide Polymorphisms in the DGAT1 Gene of Buffaloes by PCR-SSCP. Genetics and Molecular Biology, 35(3): 610613.

Sanger, F. dan Coulson, A. R. 1975. A rapid method for determining sequences in DNA by primed synthesis with DNA polymerase. Journal of Molecular Biology, 94(3): 441-448.

Smith, L. M., Sanders, J. Z., Kaiser, R. J., et al. 1986. Fluorescence detection in automated DNA 
sequence analysis. Nature, 321(6071): 674-9. doi:10.1038/321674a0.

Sunarto, 1996, Diagnostik Molekular Thalasemia, Jurnal Berkala IImu Kedokteran, vol.26(1), 44-51.

Thermann, R. 1998. Binary specification of nonsense codons by splicing and cytoplasmic translation. The EMBO Journal 17(12): 3484-3494.

Treisman, R., Orkin, S.H., and Maniatis, T. 1983. Specific Transcription and RNA Splicing Defects in Five Cloned $\beta$-Thalassaemia Genes. Nature 302: 591-6.

Warsy, A., ElHazmi, M., Al Momin, A., AlHazmi, A., and Aleem, A. 2013. Extensive Polymorphisms in Saudi Beta Thalassaemia Patieants. Biosciences Biotechnology Research Asia 10(1): 127-132.

Wintrobe, MM. 2009. Clinical Hematology. Philadelphia: Lea and Febringer. 